\title{
Interrelation of Legal Regulation of Land Plots and Buildings Located on Them
}

\author{
Irina Kuzmina* \\ Siberian Federal University \\ 79 Svobodny, Krasnoyarsk, 660041, Russia
}

Received 03.06.2016, received in revised form 07.07.2016, accepted 23.08.2016

\begin{abstract}
A land plot and buildings located on it are interconnected both physically and functionally: the building is firmly connected with the earth, it is physically reinforcedthere, and built-up land plots lose their independent significance and fulfill only a serving function of the building's location. The unity of these two different items affects their legal regulation: the definition of the subject of property rights, the establishment of the order of disposal, etc. Two legal concepts have been formed historically, whichprovide this legal commonness: establishment of the single object regulation and regulation of the common legal fate. The Russian legislation preserves the tradition of using the concept of thecommon legal fate, in particular, it establishes the right of sequence: namely, one thing should have the legal fate of the other thing. Herewith, thequestion which real thing (a land plot or a building located on it) is the main one, and which follows it, is solved quite contradictorily. For the development of the real estate market, its stability and clarity it is necessary to abandon the solution of the question of the primacy between the two undoubtedly interlinked real estate assets, and to secure the mandatory rule of their interrelationsupplementing the rules of the Civil Code of the Russian Federation regarding the objects of civil rights with the new type of property structure consisting of a land plot with buildings and structures and other things located therein and permanently connected to it, which are united by the general purpose.
\end{abstract}

Keywords: legal regulation, land plot, building, single object, common legal fate.

DOI: 10.17516/1997-1370-2016-9-9-2279-2287.

Research area: civil law.

\section{Problem Statement}

The legal regulation of things as material objects of civil relations is characterized by the fact that the civil law doctrine by analogy to the legal capability of persons is referred to as "passive legal capability of a thing" ${ }^{1}$ or "legal applicability of a thing" ${ }^{2}$, i.e. the ability of items to be the subject of civil (private) relations: relations of statics (appropriation, possession) and dynamics (circulation, exchange). The value of this method of legal regulation lies in its focus: it provides optimum "behaviour" of participants of the relations in connection with the thing, creates the best from the point of view of the social and economic processes "way of regulation expressed in the nature and scope of rights in relation to the object" ", for example, provides publicity, transparency and recognizability of the relations

(C) Siberian Federal University. All rights reserved

* Corresponding author E-mail address: kuzmina-58@mail.ru 
(property regime); the ability of the thing to break up by nature (regime of divisible and indivisible things), etc.

The legal regulation of land plots is set by the rules of civil law and the law of land. The Civil Code of the Russian Federation defines that the land belongs to immovable things (Par.1 Art. 130), which may be alienated or transferred from one person to another by other means to the extent at which their circulation is permitted by the land law (Par.3 Art. 129). Therefore, if the land legislation does not set restrictions or features, the holders of the corresponding land rights can sell them, rent and perform other actions in compliance with the rules defined by the civil law.

Besides the land plots, the legislator also refers to immovable things, everything firmly connected to the ground, that is immovable without damage disproportionate for the purpose. On this basis, buildings - civil engineering structures, which are the completed result of legal construction - are declared to be real estate. As the real estate, buildings perceive the common features of the legal regulation of immovable things as defined by civil law. However, along with kinship, they possess essential specific features that distinguish them from such real estate as land plots: special regulation of their creation (development mode) and the introduction of these land plots into civil circulation, the disposal mode (including demolition and alteration), the mode of their operation and preserving. These differences, as well as the fact that it is the land legislation, its basis and fundamental provisions that establishes the legal regulation of the land, predetermines the necessity in special legal modes for land plots and buildings.

The interrelation of legal regulation of these objects is determined not only by their belonging to different types of immovable things, but also by the presence of a special relationship between them. We are not talking about any land plot and building, but the buildings and the land plot it is located on. The position of the building, as a special immovable thing, is characterized, above all, by physical connection to the land ${ }^{4}$, a certain plot of land constituting "a familiar environment of use", the removal of which entails a disproportionate damage to the purposes of the property or its owner ${ }^{5}$. At the same time, it is impossible to use the land plot otherwise, while it is already the location of the building, its spatial basis. Such functional composition can have no effect on the "legal link between the building and the ground"6. The aim of the legislator in determining the legal status of these immovable things should be satisfaction of the need to ensure legal commonness of the functionally interconnected things when it is impractical to determine their legal fate in different ways, to encourage independent circulation of each of them. These tasks can be achieved by two methods of legal regulation: the establishment of the single object mode when dissimilar things are legally defined as a single and indivisible object ("as one thing"), or legal regulation of the common fate for dissimilar but functionally related things

\section{Legislative History of the Issue}

The legal interrelationship of the land plot and buildings located on it has a long legislative history.

It is known that the classical Roman law was basing on the following principles: the house is a part of the ground, its artificial part $^{7}$ and everything that is firmly connected to the land cannot be the object of individual rights ${ }^{8}$, it belongs to the owner of the land plot ${ }^{9}$; people who have built the building on the land that belongs to another person, cannot acquire ownership rights to it; horizontal (floor-by-floor) division of the house between several co-owners is impossible, the one who owns the land plot also owns the 
house $^{10}$. Thus, the legal regulation for the building and the land it is located on were harmonized, and the land owner was considered the owner of the building, which was built on it.

Modern legal systems are basically formed on the same principles. The UNCITRAL Legal Guide on Drawing Up International Contracts for the construction of industrial facilities, prepared by the working group of the UN Commission on International Trade Law, divides the world legal systems into two groups:

- Those with mandatory rules on the ownership of the object in the construction process and after its completion;

- Those with non-mandatory rules resolving the issue.

Both mandatory and non-mandatory rules usually set the rule that "the ownership of land includes ownership of what is located on its top and bottom" (Art. 552 of the French Civil Code) or "Ownership of the land surface entails ownership of what is above and beneath the ground" (Art. 951 of the Civil Code of Quebec), and so on. If the issue is resolved in terms of mandatory rules, then the construction object will be owned by the owner of the construction site, i.e. the land on which it is located. The non-mandatory rules provide the same solution, but with the proviso "unless otherwise provided by the agreement".

International experience is based on the concept of derivation of buildings and structures in relation to the property rights. They are considered to be "artificial attachment to the property" (land plot) (Article 954 - 964 of the Civil Code of Quebec). Accordingly, they have the same owner and legal fate. Persons which are not the owners of land plots have certain rights for buildings, including those that are close in content to the property rights. But these rights would be the rights for the property of another owned by the owner of the land plot (superficies, perpetual lease, etc.).
The pre-revolutionary Russian legislation and its application were based on the same principal provisions of the impossibility of ownership fragmentation between the land owner and the owner of the building. Buildings were considered "accessory to the land on which they were built" and were declared "the property of the one who owns the land they are located on" ${ }^{11}$. Buildings constructed on the land owned by another were considered as incremental to the land owner who is only obliged to compensate to the developer. The exception was when the owner of the land and the developer concluded the land lease contract. Then the developer was acknowledged as the house owner, but as a temporary movable thing located on this land. ${ }^{12}$ The same legal structures were used in the Draft Civil Code, according to which the ownership of land includes buildings and structures, and buildings erected on land owned by another, were considered, as a rule, to be movable things. ${ }^{13}$

Due to changes in relation to the land, which, after the famous historical event, was excluded from civil circulation, the above mentioned concepts had lost their relevance and validity. In accordance with the Decrees "On Land" dated October 27, 1917, "On the Prohibition of the real estate transactions" dated December 29, 1917 and "On the abolition of private ownership of real estate in the cities" dated August 20, 1918, the right for private ownership of land both builtup and vacant, owned by individuals, industrial companies, departments, agencies, located within the urban settlements was abolished. At the same time in major cities (with population over 10 thousand people) the right for private ownership of all residential houses with the cost or gained income exceeding the set limit was abolished, turning them into state property. And finally, it was prohibited to perform any transactions with land and buildings located on it. In the future, transfer of land plots was 
permitted only beyond the civil circulation and only for use.

The way of defining the legal regulation of buildings was different. The period of revolutionary changes in the regulation of this issue ended in 1921 -1924, when partial decommunization of residential buildings in urban areas took place; municipalized and nationalized buildings belonging to cooperative organizations were returned. These buildings, as well as buildings which were not subject to municipalization because of their insignificant value, belonged to their owners on the basis of the ownership right. In the future, this category was supplemented by buildings newly constructed by citizens, cooperative and public organizations, residential buildings acquired by citizens in the state socialistic companies and institutions, as well as public buildings and structures transferred to cooperative and public organizations. Therefore, not recognizing the right of private property for land, the legislator had acknowledged the existence of non-state (co-operative, social, personal) ownership of the buildings and facilities (Art. 54 of the Civil Code of the RSFSR, 1922; Art. 100, 103, 105 of the Civil Code of 1964). At the same time, it provided for the right of owners to establish liability in relation to buildings and structures, including those that mediate the dynamics of the property (purchase and sale of buildings, exchange, donation). Buildings and structures, as opposed to the land, were involved in the civil circulation. Of course, to the greatest extent it concerned residential buildings and to the least - industrial buildings and the like ones. Construction of buildings was fully controlled by the land owner. The development, as a way to use the land, required its transfer in accordance with the decision of competent authorities. The land for such purposes was given for unlimited use. Buildings constructed on transferred land plots became objects of state, cooperative property rights owned by public organizations or the citizen, whose name was indicated in the transfer documents. Thus, the legal regulation of land did not coincide with the legal regulation of buildings that were built on it. The exceptions were buildings, which were state property. In this case, the owner of the building was the owner of the land. In any other case, the holder of the ownership right for the building could not be the owner of the land. The status of the building owner demanded recognition of such person to be able to dispose this building, though with limitations of the law at that time. The fate of the land was determined by the principle of sequence right established by the Decree of the Central Executive Committee and the Council of People's Commissars of the RSFSR "Statement on land regulations in the cities" dated April 13, 1925: "When legally transferred from one individual to another ... the ownership right for the structures, all rights and obligations for land plots serving these structures are thus transferred to the new owners ...". Subsequently, this principle was established in the codified acts on land, in particular in Articles 87, 88 of the Land Code of the RSFSR, adopted July 1, 1970. Thus, the Soviet legislation, not allowing private ownership of land, had set special interrelation between regulation of rights for land and buildings, according to which the land under the building, in fact, was considered as belonging to the building, i.e. sharing its legal fate, it followed it (the mode of common legal fate). The prohibition to make deals with land plots did not change this reality for the built-up land, because "the transfer occurs at the will of the subject of land rights. Although de jure the land plot is not involved in the transaction regarding the property located on it, in fact such a transaction takes place, although the land is not the subject, the subject is the corresponding right for a particular land plot. ${ }^{14}$ 


\section{Solution of the Issue in Modern Russian Legislation}

This approach is maintained in the current legislation as well. The principle "The land owner is the owner of everything that is firmly connected with it" in Russian law is formulated as non-mandatory. Both the original and the derivative owner of the building can be the person who has no right of ownership for the land. Articles 266 and 269 of the Civil Code provide such a possibility for persons who own land on the rights of life-long inheritable ownership and permanent unlimited use. The legislator allows them to have such a transformation of the land plot, as its development, and recognizes the opportunity for them to become original owners of the construction facility. Resolving this way the issue of the right of ownership for the newly constructed buildings by the holders of limited property rights for the land plot, the legislator has not mentioned the most common form of land use for the purpose of development: land lease. Chapter 17 of the Civil Code, "The right of ownership and other rights for the land" for obvious reasons does not cover this problem. Neither does Chapter 34 of the Civil Code, "Lease". It is well known that Art. 607 of the Civil Code contains only reference standard to the law, which "can provide peculiar details for land lease". If there is no specific law, these particular standards are defined by the Land Code of the Russian Federation, other acts of land legislation, numerous legal acts of urban planning and construction activities. However, they do not directly ensure the nature of rights of such developers for the building or structure they have constructed. Indirectly the civil legislator reveals the attitude to it in Art. 552 of the Civil Code, which describes what rights the buyer and the seller of the building can have for the land it is located on: the ownership of the land or the right of lease or other right. The civil legislator does not exclude the status of lessee of the land where the building is located for the building owner. At the same time, the law allows to dispose the buildings if they are constructed on the land which belongs to another, without the consent of the land owner, "if it is not contrary to the terms of use of this land plot determined by law or contract" (Paragraph 3 Article 552 of the Civil Code). This applies not only to the purchase and sale of buildings (Art. 552 of the Civil Code), but also of exchange (Art. 567 of the Civil Code) and lease of the building (Par. 3 Art. 652 of the Civil Code).

Thus, the Russian legal system does not establish the unity of the subject of ownership right for the land and property that is firmly connected with it. Existing rules on the rights in relation to the land and buildings located on it are based on the principle of horizontally shared ownership. Its meaning lies in recognizing that different subjects may have property rights for the land and property rights for the building located on it. They are recognized as separate objects in terms of their cadastral registration and state registration of rights for immovable property. To ensure the legal community of the considered real estate, the Russian legislation does not use the concept of a "single object", when its elements are the land and construction changes to it (buildings and structures). The mode of a single immovable complex - a unity of things related to each other in a certain way and recognized as a common and indivisible property - introduced by the Federal Law No. 142-FZ dated July 02, 2013, made no changes to the situation (Article 133.1 of the Civil Code). To make up the specified unity, it is assumed that the composition of objects may include buildings, structures and other things. This allowed to apply the mode of the single immovable complex to homeownership ${ }^{15}$. It should be noted that this approach still leaves the unresolved issue of the fate of land that is not a part of the single real estate complex located on it although it may be functionally associated with 
it. To ensure the community of legal regulation of buildings, structures and land under them, the current Russian legislation uses the concept of a common legal fate, in particular, the right of succession, one thing should have the fate of another. For its implementation it is necessary to determine the main (dominant) and auxiliary (following it) thing. The Land Code of the Russian Federation in Sec. 5, Art. 1 establishes the "unity of the fate of the land and facilities firmly associated with it" as the principle of land legislation according to which all objects strongly associated with land follow the fate of the land, except for the cases determined by federal laws. Corresponding regulations in the Civil Code of the Russian Federation establish the ability to perform transactions in respect of buildings and structures, when the issue of the land plot is resolved at the same time (Art. 273, 552, 652). Other federal laws, as a rule, are based on the idea of the primary value of buildings and structures, when the land plot should follow their fate: Par. 1 Art. 28 of the Federal Law "On privatization of state and municipal property" dated December 21, 2001; Par. 3 of Art. 21 of the Federal Law "On Freedom of conscience and religious associations" dated September 29, 1997. The acts of the right form the same understanding of the priority: if the land plot is built up, it loses its independent significance and is perceived by the members of the civil circulation as " auxiliary" to real estate strongly related to it. For the parties, the subjects of the transactions with built-up land are buildings and structures. The land plot fulfills the function of "serving", "ancillary" property.

\section{Perspectives of Solving the Issue}

Such inconsistent solution of the issue regarding the primacy is also proposed in the text of the Bill No. 475338-6 (second reading) "On Amendments to the Civil Code of the Russian Federation and certain legislative acts of the
Russian Federation and concerning the annulment of certain legislative acts (provisions of legislative acts) of the Russian Federation". Chapter 19.2 "The ownership right for land and other natural objects" suggests a rule that the transfer of land is not permitted without the simultaneous transfer of buildings or structures located on it (Par. 4 of Art. 287). Chapter 19.3 "The ownership right for buildings and structures" establishes that the transfer of the building or structure is not permitted without the simultaneous transfer of the land plot (Par. 3 Art. 297).

It seems that the development of the real estate market, its stability and clarity requires not the solution of the dispute "what is more important" inevitable for the legal regulation of the main thing and its accessories (land or buildings and facilities firmly associated with it), but the establishment of the rule regarding their commonness and common legal fate. In such cases, it is inappropriate to determine the legal fate of the building and the land beneath it in different ways: the built-up land has only one consumer and functional purpose of being the location for the building or structure. While the building is located there, the land cannot be used for another purpose. Therefore, the right must not encourage an independent circulation of built-up land: the owner of the building during the transfer should simultaneously transfer the corresponding right for the land that serves it. In order to ensure the interests of participants of civil circulation, a corresponding mandatory rule should be established in the form of general provision and not in sections of certain types of contracts or features of regulating real rights for individual objects. It should be extended to all cases of transactions on the specified objects. Location of this provision in the structure of the Civil Code should be determined on the basis of its purpose: the corresponding rule should be present in the rules regarding objects of civil rights. 
It appears that the legal regulation of unrelated things proposed by themodern civil law needs further improvement. To complete the legal regulation, the legal modes of such compositions should be supplemented by the property set consisting of the land plot with buildings located on it and the structures and other immovable things associated with them united by the common purpose.

\section{References}

Bartoshek, M. (1989). Rimskoe parvo: poniatiia, terminy, opredeleniia [Roman Law: Concepts, Terms and Definitions], Moscow, Iurid.lit., 305 p.

Chernykh, A.V. (1995). Zalog nedvizhimosti v rossiakom prave [Real Estate Mortgage in the Rusian Law]. Moscow, Legat legal company, 56 p.

Duvernois, N.L. (1902). Chteniia po grazhdanskomu pravu [Readings on the Civil Law]. Saint Petersburg, $936 \mathrm{p}$.

Gambarov, Iu.S. (1911). Kurs grazhdanskogo prava. Chast' obshchaia. [The Series of Lectures on Civil Law. The General Part]. Saint Petersburg, 780 p.

Ikoniskaia, I.A. (1999). Zemel'noe pravo Rossiiskoi Federatsii [Land Law of the Russian Federation], Moscow, p.76.

Kasso, L.A. (1905). Zdaniia na chuzhoi zemle [Buildings on the Land Owned by Another], Moscow, 4-5.

Kasso, L.A. (1905). Zdaniia na chuzhoi zemle [Buildings on the Land Owned by Another], Moscow, $42 \mathrm{p}$.

Kasso, L.A. (1906). Russkoe pozemel'noe parvo [Russian Land Law], Moscow, 260 p.

Khvostov, V.M. (1996). Sistema rimskogo prava. Uchebnik. [The System of Roman Law. Student's Book], Spark Publishing House, 522 p.

Lapach, V.A. (2002). Sistema ob'ektov grazhdanskikh prav: teoriia i sudebnaiia praktika [The System of Civil Law Objects: Theory and Judicial Practice], Saint Petersburg, Press judicial centre, $291 \mathrm{p}$.

Mitiukov, K.A. (1912). Kurs rimskogo prava [Lecture on Roman Law], Kiev, 407 p.

Obiazatel'stva po dogovoram. Opyt kommentariia russkikh grazhdanskikh zakonov. Vyp. 1. Kommentarii na 4 knigu $1 \mathrm{ch}$. X toma svoda zakonov [Obligations under contracts. The Experience of commenting Russian civil laws. Issue 1. Comments to the $4^{\text {th }}$ book of the 1st Part of Volume X of the Code of Laws] (1914). Saint Petersburg, 739 p.

Problemy teorii gosudarstva i prava [Challenges of the Theory of State and Law] (1987). Uchebnik pod red. S.S. Alekseeva [Student's Book compiled by S.S. Alekseev], Moscow, Iurid. Lit., $259 \mathrm{p}$.

Proekt grazhdanskogo ulozheniia (s ob'iasneniiami, izvlechcennymi iz trudov Redaktsionnoi kommissii). Tom pervui. [Draft Civil Code (with explanations taken from the works of the Revision Commmittee)] (1910). Edited by I.M. Tiutriumov, Saint Petersburg, 1215 p.

Sinaiskii, V.I. Russkoe grazhdanskoe pravo [Russian Civil Law]. Obshchaia chast' $i$ veshchnoe pravo, 1. Kiev, $330 \mathrm{p}$.

Trestsova, E.V. (2015). Modernizatsiia ob'ektov nedvizhimogo imushchestva v grazhdanskom zakonodatel'stve Rossiakoi Federatsii [Modernization of the Objects of Immovable Property in Civil Law of the Russian Federation], Lex russica, 1, 67-75. 
Duvernois, N.L. (1902). Chteniia po grazhdanskomu pravu [Readings on the Civil Law]. Saint Petersburg, p. 606.

2 Lapach, V.A. (2002). Sistema ob'ektov grazhdanskikh prav: teoriia i sudebnaiia praktika [The System of Civil Law Objects: Theory and Judicial Practice], Saint Petersburg, Press judicial centre, p. 291.

3 Problemy teorii gosudarstva i prava [Challenges of the Theory of State and Law] (1987). Uchebnik pod red. S.S. Alekseeva [Student's Book compiled by S.S. Alekseev], Moscow, Iurid. Lit., 259 p.

4 Gambarov, Iu.S. (1911). Kurs grazhdanskogo prava. Chast' obshchaia. [The Series of Lectures on Civil Law. The General Part]. Saint Petersburg, p. 596.

5 Chernykh, A.V. (1995). Zalog nedvizhimostiv rossiakom prave [Real Estate Mortgage in the Rusian Law]. Moscow, Legat legal company, p. 56.

Kasso, L.A. (1905). Zdaniia na chuzhoi zemle [Buildings on the Land Owned by Another], Moscow, $42 \mathrm{p}$.

Mitiukov, K.A. (1912). Kurs rimskogo prava [Lecture on Roman Law], Kiev, p. 69.

Khvostov, V.M. (1996). Sistema rimskogo prava. Uchebnik. [The System of Roman Law. Student's Book], Spark Publishing House, p. 324.

9 Bartoshek, M. (1989). Rimskoe parvo: poniatiia, terminy, opredeleniia [Roman Law: Concepts, Terms and Definitions], Moscow, Iurid.lit., 305 p.

10 Kasso, L.A. (1905). Zdaniia na chuzhoi zemle [Buildings on the Land Owned by Another], Moscow, 4-5.

11 Obiazatel'stva po dogovoram. Opyt kommentariia russkikh grazhdanskikh zakonov. Vyp. 1. Kommentarii na 4 knigu 1 ch. X toma svoda zakonov [Obligations under contracts. The Experience of commenting Russian civil laws. Issue 1. Comments to the $4^{\text {th }}$ book of the 1st Part of Volume X of the Code of Laws] (1914). Saint Petersburg, 149.

12 Kasso, L.A. (1906). Russkoe pozemel'noe parvo [Russian Land Law], Moscow, pp. 122-123; Sinaiskii, V.I. Russkoe grazhdanskoe pravo [Russian Civil Law]. Obshchaia chast'i veshchnoe pravo, 1. Kiev, 330.

13 Proekt grazhdanskogo ulozheniia (s ob'iasneniiami, izvlechcennymi iz trudov Redaktsionnoi kommissii). Tom pervui. [Draft Civil Code (with explanations taken from the works of the Revision Commmittee)] (1910). Edited by I.M. Tiutriumov, Saint Petersburg, p.63, p.615. It should be noted that the during the discussion of the Draft Code there were doubts in terms of reasonability and practicability of such solutions in cases, when developers of the house have the right for land use (lease). See Kasso, L.A. Russkoe pozemel'noe parvo [Russian Land Law], p.123.

14 Ikoniskaia, I.A. (1999). Zemel'noe pravo Rossiiskoi Federatsii [Land Law of the Russian Federation], Moscow, p.76.

15 Trestsova, E.V. (2015). Modernizatsiia ob'ektov nedvizhimogo imushchestva v grazhdanskom zakonodatel'stve Rossiakoi Federatsii [Modernization of the Objects of Immovable Property in Civil Law of the Russian Federation], Lex russica, 1, 67-75.

\title{
Соотношение правовых режимов
}

\section{земельных участков}

\section{и расположенных на них зданий}

\author{
И. Кузьмина \\ Сибирский федеральный университет \\ Россия, 660041, Красноярск, пр. Свободный, 79
}

Земельный участок и расположенное на нем здание связаны между собой и физически, и функиионально: здание прочно связано с землей, физически в ней укреплено, а застроенные земельные участки утрачивают самостоятельное значение и выполняют лишь обслуживаютую функиию места расположения здания. Единение этих двух разных объектов недвижимости оказывает влияние на их правовой режим: определение субъекта права собственности, установление порядка распоряжения и т.д. Исторически сформировались две правовые концепиии обеспечения такой правовой общности: установление режима единого объекта и режима единой правовой судьбы. В российском законодательстве сохраняется традиция использования концепции единой правовой судьбы, в частности, закрепляется правило следования, а именно: одна вещь следует правовой судьбе другой вещи. При этом противоречиво решается вопрос о том, какой объект недвижимости (земельный участок или расположенное на нем здание) является главной вешью, а какой-следует за ней. Для развития рынка недвижимости, обеспечения его стабильности и ясности необходимо отказаться от решения вопроса о главенстве между двумя несомненно взаимосвязанными объектами недвижимости, а закре- 
пить императивное правило об их общности, дополнив нормы Гражданского кодекса РФ об объектах гражданских прав новым видом имущественного комплекса, состоящего из земельного участка с расположенными на нем зданиями и сооружениями и иными постоянно с ними связанными вещали, объединенными общиим назначением.

Ключевые слова: правовой режим, земельныий участок, здание, единый объект, единая правовая судьба.

Научная специальность: 12.00.03 - гражданское право; предпринимательское право; семейное право; международное частное право (юридические науки). 